\title{
O KSZTAŁT POLICJI W II RZECZYPOSPOLITEJ. OD WZORCA SAMORZĄDOWEGO DO MODELU PAŃSTWOWEGO
}

\section{Robert Litwiński}

Uniwersytet Marii Curie-Skłodowskiej w Lublinie

\author{
ABSTRACT \\ THE ISSUE OF POLICE IN THE SECOND REPUBLIC OF POLAND: \\ FROM THE LOCAL GOVERNMENT MODEL TO THE STATE MODEL
}

The article discusses an important aspect associated with the functioning of every state, namely, the question of ensuring public security by an effective police institution. The significance of these issues was recognized already in pre-partition Poland. No wonder that during the world conflict of 1914-1918, when the hopes of Poland regaining its independence appeared, there also arose ideas for ensuring public security, peace and order in the reborn state. The first to emerge were citizens' bodies: underlying their actions was the intention to secure persons and their property after the withdrawal of the Russians from the Kingdom of Poland. The initiatives they took resulted first in the formation of citizens' organizations, which were subsequently taken over by local government authorities. This made it possible to develop a local government model of police organization with a territorially limited range of operation. However, when the issues of public security began to be considered from the angle of administering the territory of the reborn Republic as a whole, the concept that prevailed was that of a centralized state police institution, which was brought into effect after independence was regained.

Keywords: People's Militia, City Militia, Municipal Militia, State Police, Police of the Silesian Province, Citizens' Guard, National Gendarmerie.

Słowa kluczowe: Milicja Ludowa, Milicja Miejska, Milicja Komunalna, Policja Państwowa, Policja Województwa Śląskiego, Straż Obywatelska, Żandarmeria Krajowa.

Każde państwo powinno dysponować organizacjami, których zadaniem jest zagwarantowanie bezpieczeństwa obywatelom i ich mieniu, utrzymanie spokoju, porządku publicznego oraz zapewnienie przestrzegania obowiązujących przepisów 
prawa. Tego rodzaju instytucje były także obecne w Polsce przedrozbiorowej. Okres długoletniej niewoli spowodował jednak, że kilka pokoleń Polaków doświadczało działalności policji państw zaborczych, w konsekwencji czego trudno było mówić o własnych tradycjach w tym względzie, a do stworzenia pierwszych rodzimych formacji miało dojść w czasie Wielkiej Wojny ${ }^{1}$.

Jeszcze przed jej wybuchem niektórzy „,co znaczniejsi” obywatele Królestwa Polskiego przeczuwający, że organa rosyjskie, opuszczając jego obszar, skażą mieszkańców na potencjalne zagrożenie, zasiali ideę systemowego rozwiązania kwestii polskich organizacji bezpieczeństwa publicznego. W konsekwencji jako pierwsze pojawiły się, co zresztą naturalne, biorąc pod uwagę ówczesne realia, organizacje o charakterze oddolnym.

\section{WOKÓŁ INICJATYW „SAMORZĄDOWYCH”}

Gdy tylko pod koniec lipca 1914 roku rozpoczęto ewakuację wchodzącego w skład guberni piotrkowskiej Zagłębia Dąbrowskiego, reprezentanci, głównie kręgów przemysłowych, zaproponowali powołanie do życia organizacji, której zadaniem byłoby zapobieżenie spodziewanym grabieżom. Podczas pertraktacji z przedstawicielami rosyjskiej administracji osiągnięto konsensus, zgodnie z którym przewidywano utworzenie w poszczególnych gminach straży obywatelskich. Już 30 lipca pierwsze takie formacje, podporządkowane Komendzie Okręgu Straży Obywatelskich Zagłębia, kierowanej przez Kazimierza Srokowskiego, zapoczątkowały przejmowanie posterunków zajmowanych dotychczas przez policję rosyjską ${ }^{2}$.

Genezę powoływania ówczesnych straży, głównie przez ,wybitniejszych obywateli" w poszczególnych miastach, w pełni oddają słowa rosyjskiego naczelnika powiatu włocławskiego Piotra Michajłowicza Lapunowa, który podczas spotkania w tamtejszym magistracie powiedział do zebranych mieszkańców:

Panowie, [...] zanim władze moje pozwolą mi wyjechać z miasta, miasto jest wydane na łup motłochu, bo wojska już wyszły. Panowie, jestem pewien, że motłoch rzuci się do rabunku. Na

\footnotetext{
${ }^{1}$ Na ten temat zob. m.in.: A. Z a h or s ki, Centralne instytucje policyjne w Polsce w dobie rozbiorów, Warszawa 1959, s. 284; A. A bram s ki, J. K on i e c zny, Justycjariusze, hutmani, policjanci. Z dziejów stużb ochrony porzadku w Polsce, Katowice 1987, s. 9-122.

${ }_{2}$ Dziesięciolecie Stużby Bezpieczeństwa w Polsce Odrodzonej, red. E. Grabow iecki, Warszawa 1925, s. II; A. Misiuk, Tworzenie się polskich organów policyjnych w okresie I wojny światowej (1914-1918), „Problemy Kryminalistyki” 1987, nr 176, s. 249; W. S tarości a k, Kazimierz Srokowski - pierwszy przewodniczacy Rady Miejskiej w latach 1917-1924, „Raptularz Kulturalny” 2005, nr 1, s. 54-55; R. Litwiński, O polska policję. Koncepcje organizacji bezpieczeństwa publicznego na ziemiach polskich w czasie Wielkiej Wojny [w:] Lata Wielkiej Wojny. Dojrzewanie do niepodległości 19141918, red. D. Grin berg, J. S nop k o, G. Zaki iew ic z, Białystok 2007, s. 245; idem, O bezpieczeństwo wewnętrzne odrodzonej Rzeczypospolitej, „Przegląd Historyczno-Wojskowy” 2018, nr 1-2, s. 220-221.
} 
gwałt organizujcie straż bezpieczeństwa, nie ma chwili do stracenia. To są moje ostatnie przestrogi, jakie wam daję; radźcie sami, gdyż ja już żadnej władzy nie posiadam³.

W lipcu rozpoczęto również formowanie Straży Obywatelskiej (SO) w Warszawie. W zaprezentowanej w początkach sierpnia rosyjskiemu generał-gubernatorowi Jakowowi Grigorjewiczowi Żylinskiemu koncepcji opowiadano się za: zagwarantowaniem aprowizacji, uruchomieniem wsparcia finansowego dla mieszkańców stolicy, zapewnieniem zatrudnienia osobom pozbawionym środków do życia, zagwarantowaniem bezpieczeństwa publicznego. Rosjanie ten ostatni postulat uznali za przedwczesny i nie wyrazili nań zgody. Z tego też względu prace zmierzające do utworzenia formacji o charakterze policyjnym prowadzono w konspiracji. Przebieg ówczesnych wypadków spowodował, że dopiero w październiku warszawska Straż Obywatelska mogła, co prawda już oficjalnie, rozpocząć swą działalność, ale była to aktywność krótkotrwała, gdyż odwołana wówczas ewakuacja spowodowała zawieszenie jej służby. Nie zmienia to jednak faktu, że właśnie tamtejsza formacja miała wkrótce odegrać istotną rolę w tworzeniu modelu służby policyjnej dla odradzającego się państwa ${ }^{4}$.

Po opuszczeniu przez Rosjan Warszawy latem 1915 roku straż mogła ponownie podjąć się swej misji, a tamtejszy Komitet Obywatelski wezwał mieszkańców do złożenia w ratuszu posiadanej broni, przekazywania koni i rowerów oraz do spokojnego zachowywania się i dbania o utrzymanie porządku. W odezwie zapowiedziano jednocześnie, że wszelkie próby nieposłuszeństwa i wykroczeń zakłócających spokój publiczny będą surowo karane ${ }^{5}$.

Zaznaczyć należy, że podobne instytucje, działające pod szyldami straży obywatelskich, straży bezpieczeństwa lub milicji obywatelskich, tworzono również w innych miastach Królestwa Polskiego, a poza jego granicami Miejską Straż Obywatelską powołano z inicjatywy władz municypalnych we Lwowie w sierpniu 1914 roku. Tam też już miesiąc później utworzono nową formację - Milicję Miejską (MM) ${ }^{6}$.

Wypada podkreślić fakt, że zgoda władz rosyjskich na tworzenie tego rodzaju organizacji była jedynie efektem zmieniającej się sytuacji militarnej. Nie byłoby

${ }^{3}$ Cyt. za: H. Wardęs k i, Moje wspomnienia policyjne, Warszawa 1926, s. 10-11.

${ }^{4}$ Sprawozdanie Komitetu Obywatelskiego miasta Warszawy. Sierpień-grudzień 1914, Warszawa 1915, s. 3; Księga pamiątkowa Straży Obywatelskiej st. m. Warszawy i Przedmieść 5.VIII.1915 31.1.1916, oprac. J.P., Warszawa-Lwów 1916, s. 3-4; H. Wardę s ki, op. cit., s. 27; A. Kroń sk i, Straż Obywatelska m. st. Warszawy 1915 roku, Warszawa 1934, s. 5; R. Litwiński, O polska policję..., s. 245-246; idem, O bezpieczeństwo wewnętrzne..., s. 221.

${ }_{5}^{5}$ Księga pamiątkowa..., passim; Okupacja Warszawy. Zbiór dokumentów i głosów prasy dotyczacych sprawy polskiej w zwiazku z zajęciem Warszawy przez wojska niemieckie. Sierpień 1915 r., Fryburg 1915, s. 5; Sprawozdanie Komitetu Obywatelskiego 1915 r. Czesść 2-ga (okres od 5 sierpnia do 31 grudnia 1915 r.), Warszawa 1917, s. 3; H. Wardę ski, op. cit., s. 35-36, 39-40; A. Kroński, op. cit., s. 9-10; por. Dziennik Juliusza Zdanowskiego, t. I, 22 VI 1915-29 IV 1917, oprac. J. Faryś, T. Sikorski, H. Walczak i A. Wątor, Szczecin 2013, s. 98-99.

${ }^{6}$ Archiwum Państwowe w Lublinie (dalej: APL), Lubelski Obywatelski Komitet Gubernialny, Wstęp do inwentarza, k. 1-4; W. Strzelec ki, Bezpieczeństwo na ziemiach Polski. Od kmiecia grodowego do granatowej armii, Warszawa 1934, s. 165-172; H. Kramarz, Samorząd Lwowa w czasie pierwszej wojny światowej i jego rola w życiu miasta, Kraków 1994, s. 38, 47. 
o tym mowy, gdyby Rosjanie nadal mocno trzymali się w Królestwie. Słusznie też zauważył Jerzy Kochanowski, że zakładano, iż po powrocie carskiej administracji wszystkie straże ulegną rozwiązaniu. W przekonaniu Rosjan miały one mieć jedynie charakter tymczasowy ${ }^{7}$.

Zastanawiając się z kolei nad celami strony polskiej, wypada zadać pytanie, ile w tych działaniach było realnych planów zmierzających do stworzenia rodzimego systemu bezpieczeństwa, a ile po prostu chęci ochrony własnego mienia przed grabieżą. Wydaje się, że w początkowych miesiącach Wielkiej Wojny dominował przede wszystkim ten drugi czynnik. Z kolei państwa centralne, wkraczające na teren Królestwa, do funkcjonujących organizacji porządkowych odnosiły się koniunkturalnie. Początkowo zgodziły się na ich funkcjonowanie, ale następnie stopniowo zaczynały ograniczać swobodę działalności tych organizacji. Okupanci zdawali sobie bowiem sprawę, że członkowie istniejących straży dobrze znali lokalne problemy i mogli odciążyć okupacyjne siły policyjne. Dlatego chętnie się nimi posługiwano. Kiedy Austriacy i Niemcy sami zaczęli zapoznawać się z sytuacją, w zakresie dla nich satysfakcjonującym, zdecydowali się na ograniczanie polskiej aktywności ${ }^{8}$.

Z kronikarskiego obowiązku należy jednak odnotować, że bardzo często początki tych obywatelskich formacji były bardzo trudne i nierzadko odbiegały od lansowanej w późniejszych latach tezy o masowej chęci służenia społeczeństwu. Można w tym miejscu przytoczyć chociażby relację Henryka Wardęskiego, który zanim wstąpił do włocławskiej SO, zaobserwował, że straży daleko było do ideału. Tak na ten temat pisał:

Nieraz zatrzymanych bito i popychano. Sam byłem świadkiem takiej przykrej sceny, gdzie znanego obywatela miejscowego, zegarmistrza, pobił młodzieniec, dowodzący patrolem. Innego obywatela, właściciela nieruchomości, człowieka chorego na nogi, zatrzymano, a następnie gwałtem prowadzono do biura straży, bijąc go niemiłosiernie nahajami po chorych nogach. Za drobne przewinienia wymierzano na wieży strażackiej doraźne kary chłosty. W ten sposób załatwiano nawet spory cywilne. Zaczęło się bezprawie. Członkowie Straży Obywatelskiej załatwiali porachunki osobiste ze swymi przeciwnikami, nienależącymi do Straży Obywatelskiej"'.

Inaczej jednak ocenił formację, kiedy ją likwidowano, a on sam miał za sobą doświadczenie służby w jej szeregach na terenie dwóch miast: „Jako organizacja, która powstała samorzutnie, która była wytworem chwili i konieczności dziejowej, która z góry wiedziała, że będzie tylko przejściową organizacją, trzeba przyznać, że położyła duże zasługi dla społeczeństwa i ludności miasta"10. I z tą opinią należy się zgodzić. Ponadto te obywatelskie inicjatywy nie dość, że pobudzały samorządność, to jeszcze okazały się prawdziwą szkołą kadr dla przyszłej policji odrodzonej Rzeczypospolitej.

7 J. Ko ch hanow s ki, O ksztalt polskiej policji-styczeń 1917 - listopad 1918, „Przegląd Historyczny" 1986, t. LXXVII, z. 3, s. 481.

${ }^{8}$ A. Kroń ski, op. cit., s. 12-14; R. Litwiński, O polska policję..., s. 248; idem, O bezpieczeństwo wewnętrzne..., s. 222.

${ }^{9}$ H. Ward ęski, op. cit., s. 13-14.

${ }^{10}$ Ibidem, s. 58; por. Sprawozdanie Komitetu Obywatelskiego 1915 r. Część 2-ga..., s. 18-19. 
W lutym 1916 roku warszawską Straż Obywatelską, zgodnie z zaleceniami władz niemieckich, przekształcono w Milicję Miejską. Podobny mechanizm zastosowano również w innych miastach Królestwa. Milicja, będąca organem zarządu miejskiego, pełniła równocześnie funkcję pomocniczego organu władz niemieckich, zarówno wojskowych, jak i cywilnych. Podlegała ponadto niemieckiemu prezydentowi policji Ernstowi von Glasenappowi w Warszawie. Milicje, które powstawały przez przekształcanie byłych straży, składały się z funkcjonariuszy płatnych, umundurowanych (choć to nastąpiło dopiero po pewnym czasie) i uzbrojonych przede wszystkim w broń białą. Nowa formacja - będąca organem władz municypalnych - miała zająć się dbałością o porządek na ulicach, dobro publiczne w zakresie spraw sanitarnych, przemysłowych i budowlanych. Milicji zabroniono jednak prowadzenia spraw kryminalnych i obyczajowych, które zastrzeżono dla policji niemieckiej. Istotnym ograniczeniem był również zakaz interwencji wobec osób wojskowych i niemieckich urzędników ${ }^{11}$.

Podkreślić należy fakt, że milicje miejskie rozwijały się przede wszystkim na terenie byłego Królestwa Kongresowego i podobnie jak straże obywatelskie nie stanowiły nigdy jednolitej organizacji kierowanej centralnie. Opierały się na wzorcach wypracowanych przez milicję warszawską, odgrywającą wówczas dominującą rolę. Ale w ich szeregach zaczęto wprowadzać szkolenie wojskowe, co miało odegrać w późniejszym czasie niebagatelną rolę ${ }^{12}$.

\section{O MODEL PAŃSTWOWY}

Doświadczenia, zdobywane przez straże i milicje działające w poszczególnych miastach, spowodowały, że coraz częściej zastanawiano się nad charakterem przyszłej formacji policyjnej. Pod uwagę brano zarówno model samorządowy, jak i państwowy. Te dylematy stały się bardziej widoczne szczególnie po akcie 5 listopada. Jak stwierdził Kochanowski, oczywiste bowiem się stało, że zapowiadane w nim Królestwo Polskie nie mogło istnieć bez organizacji bezpieczeństwa publicznego ${ }^{13}$. Otwarte pozostawało pytanie o jej formę. Nie ulega wątpliwości, że sprawność wykonywania obowiązków oraz sposób zarządzania w skali całego kraju skłaniały bardziej ku drugiemu rozwiązaniu. I ono też zaczęło dominować od 1917 roku. Zdawano sobie bowiem sprawę, że działalność formacji podporządkowanych wielu

${ }^{11}$ Regulamin stużbowy dla Milicji Miejskiej st. m. Warszawy, Warszawa 1916, s. 3-16; H. Wardęsk i, op. cit., s. 70-71; W. S tr ze le c k i, op. cit., s. 160-164; G. Gryz, Milicja Miejska miasta stołecznego Warszawy [w:] Od straży obywatelskich do Policji. Stużby porzadkowe na ziemiach polskich w XX wieku, red. R. Łaszewski i B. Sprenge1, Włocławek 2007, s. 37-40.

${ }_{12}$ R. Litw iń s ki, O polska policję..., s. 249; Kalendarzyk Polityczno-Historyczny miasta stolecznego Warszawy na 1917 rok, Warszawa b.d.w., s. 94; H. Ward ę ski, op. cit., s. 70-71, 80, 132-133, 147; W. Strzelecki, op. cit., s. 160-164.

13 J. Kochanowski, op. cit., s. 482. 
nieskoordynowanym czynnikom decyzyjnym, a takimi byłyby poszczególne samorządy, stworzy jedynie pozory bezpieczeństwa ${ }^{14}$.

Pierwsze prace koncepcyjne związane $\mathrm{z}$ zapewnieniem bezpieczeństwa publicznego w kontekście ogólnokrajowym możemy łączyć z Tymczasową Radą Stanu (TRS), w której utworzono Departament Spraw Wewnętrznych. W jego skład wszedł między innymi pierwszy naczelnik warszawskiej MM Franciszek Radziwiłł. W styczniu 1917 roku pod obrady zgłoszono wniosek o utworzenie Krajowej Straży Bezpieczeństwa Publicznego. Niestety ten postulat pozostał jednak tylko projektem, gdyż Niemcy nie chcieli się zgodzić na utworzenie ogólnokrajowej, scentralizowanej policji. To właśnie w TRS wyraźnie zaznaczyły się rozbieżności dotyczące charakteru przyszłej organizacji bezpieczeństwa publicznego. Jak pisał Kochanowski: „Podstawą nieporozumień stała się sprawa wewnętrznej organizacji policji: czy budować małe i słabe autonomiczne policje gminne i wiejskie, czy też stworzyć organizację ogólnokrajową". Porozumienia jednak w tej kwestii nie osiągnięto ${ }^{15}$. Nie zdecydowano się więc, czy ma to być model policji państwowej zarządzanej przez organ centralny, czy też milicji municypalnych kierowanych przez organa samorządu miejskiego lub wiejskiego. Ponadto rozważano rozwiązanie pośrednie, tj. system istniejący we Francji, gdzie funkcjonowały zarówno policja komunalna, jak i państwowa.

O ile akt 5 listopada stworzył możliwość (przynajmniej teoretycznie) pracy nad przygotowaniem podstaw przyszłej jednolitej służby bezpieczeństwa, o tyle to dopiero Rada Regencyjna podjęła pełniejsze prace koncepcyjne. W tej aktywności na uwagę zasługują przede wszystkim starania Mariana Borzęckiego służącego w czasie Wielkiej Wojny w warszawskiej SO i MM, a następnie kierującego Wydziałem Policji w Sekcji Administracyjnej Ministerstwa Spraw Wewnętrznych w rządzie Jana Kucharzewskiego. Prawdopodobnie to podczas pełnienia tej ostatniej funkcji powstał referat poświęcony organizacji policji w Królestwie Polskim. Borzęcki opowiadał się w nim za formacją cywilną, ale o charakterze wojskowym i do tego umundurowaną, uzbrojoną oraz podporządkowaną władzom państwowym poprzez resort spraw wewnętrznych, składającą się z funkcjonariuszy zawodowych o statusie urzędników państwowych. Wypowiadał się przy tym przeciwko podporządkowaniu policji lokalnym samorządom, bo uważał, że nie będą one w stanie z niej właściwie korzystać ze względu na brak stosownych kompetencji ${ }^{16}$.

Wielce prawdopodobne, że między innymi na tej podstawie minister spraw wewnętrznych Jan Stecki sformułował swój pogląd, zgodnie z którym obowiązki związane z koniecznością utrzymania bezpieczeństwa publicznego powinny znaleźć się w kompetencjach ogólnopolskiej, państwowej służby policyjnej ${ }^{17}$. Dostrzegając skomplikowaną sytuację $\mathrm{W}$ zakresie utworzenia organizacji bezpieczeństwa

${ }^{14}$ R. Litwińs ki, O polska policję..., s. 250; idem, O bezpieczeństwo wewnętrzne..., s. 223.

15 J. Ko ch h now sk i, op. cit., s. 482-484; J.Z. P aj ą k, O rząd i armię. Centralny Komitet Narodowy (1915-1917), Kielce 2003, s. 177-179; R. Lit wińs k i, O bezpieczeństwo wewnętrzne..., s. 223.

16 Uwagi ogólne o organizacji policji w Król. Polskiem, „Milicjant” 1919, nr 2, s. 4-6.

${ }_{17}$ Biblioteka Uniwersytecka Katolickiego Uniwersytetu Lubelskiego (dalej: BUKUL), Archiwum Jana Steckiego (dalej: AJS), rkps 571, Zasady tworzenia polskiej administracji i policji opracowane w 1918 r., k. 3-4. 
publicznego, podkreślał, że jej powołanie będzie wymagało czasu, a w związku z tym stosowne kroki należałoby podjąć jak najszybciej. Do tego czasu służbę powinny pełnić milicje miejskie i gminne, które następnie zostałyby rozwiązane. Przekonywał, że nie będzie można liczyć na policję okupantów. Składała się ona bowiem z ludzi obcych społeczeństwu, zarówno pod względem pochodzenia, jak i języka, wobec czego trudno było przypuszczać, że zagwarantuje skuteczne zwalczanie przestępczości. Różne przypadki łamania prawa pokazywały - jego zdaniem - że jeżeli policja niemiecka nie zdołała wykryć i zapobiec pewnym zdarzeniom, to bezradna będzie również nieuzbrojona $\mathrm{MM}^{18}$.

Gdy deliberowano nad modelem polskiej administracji, to za jedno z najważniejszych zadań uznano powołanie ogólnokrajowej policji o charakterze państwowym lub przynajmniej stworzenie dla niej szerokiego zaplecza kadrowego. Słuszność miał Stecki, który twierdził:

Władza, pozbawiona aparatu wykonawczego, jest bezsilną; poczynania władzy takiej są daremne, a samo jej istnienie może być raczej szkodliwem, niż pożytecznem. Lepiej jest rządzić na razie przez jakiś czas na podstawie praw wadliwych i przepisów mniej doskonałych, lecz mieć środki do nakazania posłuchu tym prawom i do utrzymania ładu, aniżeli snuć plany reform, opracowywać ulepszenia prawodawstwa, wydawać doskonałe przepisy i nie posiadać organów wykonawczych do nakazania uległości prawu. Zasada ta szczególnie ważna jest w warunkach, w jakich tworzy się państwo polskie, zagrożone od wewnątrz skutkami głębokiego rozstroju gospodarczego i niewyrobienia politycznego oraz podminowane niebezpieczną agitacją zewnętrzną ${ }^{19}$.

Stecki był świadom, że działalność prewencyjno-represyjną trzeba będzie prowadzić zarówno wobec przestępców kryminalnych, jak i politycznych wywrotowców ${ }^{20}$.

Można przyjąć, że wiosną 1918 roku w MSW ostatecznie przeważyło stanowisko, według którego najlepszym rozwiązaniem będzie utworzenie jednolitej policji, zorganizowanej na wzór żandarmerii i uzależnionej od władz państwowych. Dopuszczano co prawda myśl o dalszym istnieniu formacji komunalnych, które w określonych miastach miałyby się zajmować kontrolą ruchu ulicznego i pozostawały na utrzymaniu gmin miejskich, ale w zakresie zadań związanych z zapewnieniem bezpieczeństwa wewnętrznego podlegałyby one policji ${ }^{21}$.

W trakcie narady zorganizowanej w ministerstwie 26 marca 1918 roku postanowiono, że przyszła państwowa policja, podporządkowana ministrowi spraw wewnętrznych, powinna być zorganizowana na wzór wojskowy, a więc umundurowana, odpowiednio wyszkolona i uzbrojona, oraz odpowiadać za zapewnienie bezpieczeństwa, spokoju i porządku publicznego. W związku z tym zwierzchnictwo nad nią w powiatach planowano powierzyć starostom, podlegającym naczelnikom poszczególnych województw, którzy zarządzaliby służbą bezpieczeństwa na

18 Ibidem, k. 4.

${ }^{19}$ Ibidem, k. 7-9v.

${ }^{20}$ Ibidem; R. Litwińs ki, O bezpieczeństwo wewnętrzne..., s. 224.

${ }^{21}$ BUKUL, AJS, rkps 571, Plany J. Steckiego przygotowane dla Komisji Mieszanej w przedmiocie przejmowania administracji z $10 \mathrm{~V}$ 1918, k. 67-69; R. Litwiński, O bezpieczeństwo wewnętrzne..., s. 224. 
podporządkowanych sobie terenach. Wszyscy urzędnicy i funkcjonariusze policji mieli zostać zaliczeni w skład urzędników państwowych i otrzymywać pobory ze skarbu państwa ${ }^{22}$.

Ostateczne poglądy ówczesnych projektodawców na sprawę koncepcji przyszłego organu bezpieczeństwa publicznego możemy poznać po lekturze projektu dekretu o tymczasowej organizacji policji, wniesionego pod obrady rządu 20 października 1918 roku. Przygotowując tę koncepcję, przeanalizowano rozwiązania policyjne zastosowane w Wielkiej Brytanii, Francji, Niemczech i Austrii jako krajach przodujących pod względem rozwiązań administracyjnych, oraz Rosji, której organa odcisnęly znaczne piętno na życiu i świadomości Polaków. Uznano, że ze względu na możliwość występowania powikłań politycznych i wstrząsów społecznych (możemy w związku z tym przyjąć, że przepowiedziano wydarzenia, które nastąpiły na ziemiach polskich na przełomie 1918 i 1919 r.) należy opowiedzieć się za koncepcją organów państwowych. Zdawano sobie bowiem sprawę z niedoboru kandydatów odpowiednio przygotowanych do realizowania samorządowych obowiązków. Opowiedziano się w związku z tym za koniecznością utworzenia silnej, scentralizowanej, ogólnopaństwowej policji. Co ciekawe, nie wykluczano jednak powołania w przyszłości formacji podporządkowanych samorządom, które byłyby odpowiedzialne za pewne sfery działalności administracji (policja sanitarna, budowlana, targowa, polowa i leśna) ${ }^{23}$.

Należy przyznać, że projekt dekretu o tymczasowej organizacji policji w Polsce jest interesującą lekturą, tym bardziej że wiele jego założeń znalazło zastosowanie przy tworzeniu ustawy o Policji Państwowej w 1919 roku. Przede wszystkim, już na wstępie, rozwiązywał on sprawę dotychczasowych milicji samorządowych. Przewidywał mianowicie, że istniejące organizacje komunalne, powiatowe lub gminne zostaną upaństwowione, a zwierzchnictwo nad nową policyjną formacją zostanie oddane w ręce ministra spraw wewnętrznych. Swoje prerogatywy miał on realizować poprzez terenowe władze polityczne. Można więc stwierdzić, że przeważyła idea dominacji czynnika administracyjnego w zakresie zapewnienia bezpieczeństwa, spokoju i porząadku publicznego ${ }^{24}$. Powyższa koncepcja została przyjęta. Podczas posiedzenia ustalono, że w Królestwie Polskim, w momencie przejęcia od okupantów administracji państwowej, zostanie powołana do życia Straż Policyjna Państwowa, a działające dotychczas organizacje bezpieczeństwa zostaną upaństwowione i podporządkowane ministrowi spraw wewnętrznych ${ }^{25}$.

${ }^{22}$ BUKUL, AJS, rkps 571, Zarząd Królestwa Polskiego (projekt z III 1918 r.), k. 88, 107; BUKUL, AJS, rkps 571, Ustawa o ustroju administracyjnym Królestwa Polskiego (projekt), k. 161-165, 181-182; J. Kochanowski, op. cit., s. 487.

${ }^{23}$ BUKUL, AJS, rkps 571, Pismo MSW do Rady Ministrów „Przepisy Tymczasowej Organizacji Policji" z 20 X 1918 r., k. 189-195v.; J. K o c h a now s ki, op. cit., s. 490; R. Lit w iń s ki, Obezpieczeństwo wewnętrzne..., s. 225.

${ }^{24}$ BUKUL, AJS, rkps 571, Pismo MSW do Rady Ministrów „Przepisy Tymczasowej Organizacji Policji” z 20 X 1918 r., k. 189-195v.; R. Litw ińs k i, O polska policję..., s. 255; idem, O bezpieczeństwo wewnętrzne..., s. 225-226.

${ }^{25}$ BUKUL, AJS, rkps 571, Dekret Rady Regencyjnej o zorganizowaniu Straży Policyjnej Państwowej, wniesiony na Radę Ministrów 20 X 1918 r., k. 197; R. Litwiński, O bezpieczeństwo wewnętrzne..., s. 226. 


\section{KU POLICJI PAŃSTWOWEJ}

Konfrontacja dwóch koncepcji, tj. formacji o charakterze samorządowym lub ogólnopaństwowym, doprowadziła co prawda do zwycięstwa tej ostatniej, niemniej jednak w pierwszych miesiącach niepodległości pojawiło się kolejne stanowisko, popierające tezę przekształcenia partyjnej organizacji porządkowej, za jaką należy uznać chociażby Milicję Ludową Polskiej Partii Socjalistycznej, w ogólnopaństwową milicję. Poza tym zaczęto się zastanawiać, czy organizacja bezpieczeństwa publicznego powinna mieć charakter wojskowy w postaci żandarmerii, czy też należałoby powołać formację cywilną. Jakby tego było mało, rywalizacja polityczna spowodowała, że niemal każde ugrupowanie chciało posiadać paramilitarną organizację i zmierzało do uczynienia zeń organu bezpieczeństwa publicznego. Stąd wynikał między innymi szybki rozwój Milicji Ludowej. Co ciekawe, pojawiały się nawet głosy, że Polacy w swoim państwie sami będą dbali o własne bezpieczeństwo i nie potrzebują w związku z tym żadnej policji ${ }^{26}$. Jędrzej Moraczewski stwierdzał wręcz, nota bene zgodnie z poglądami socjalistów, że Europa zmęczona wojną zerwie z militaryzmem i zastąpi go powszechnym uzbrojeniem ludu i ochotniczymi milicjami, a ML uważał za zalążek tej nowej formy obrony ojczyzny ${ }^{27}$.

Możliwe, że o podjętych wkrótce decyzjach zadecydowało stanowisko Józefa Piłsudskiego, które przytacza w swym dzienniku Juliusz Zdanowski. Aby je lepiej zrozumieć, warto przywołać dłuższy zapis jego relacji z wizyty u Naczelnika Państwa, który

po wysłuchaniu wszystkiego oświadczył, że porządku w kraju nie ma czym robić. Że każdy rząd byłby w tym samym położeniu. Że obecnymi rządami łatwiej, bo ma[ją] zaufanie warstw ludowych. (Zaufanie to jest mierzone ilością osób okrzykujących dawane im à profu$\operatorname{sion}^{28}$ obietnice. Będzie tak długo trwało, póki się nie sprzykrzy czekać na ich zrealizowanie). Że bezwzględnie jest przeciwny mieszaniu się wojska do spraw z wojskiem nie związanych, że wszelkie istniejące milicje muszą być podporządkowane władzy administracyjnej. Gdy podkreśliłem, że lepiej by było uzależnić [je] od żandarmerii wojskowej, odpowiedział, że tej rzeczy jeszcze nie przesądził. Natomiast zapowiedział, że sprawę stosunku milicji do administracji i kompetencji samorządu w tych rzeczach [załatwi] w dniach najbliższych akt normujący te stosunki najpierw w Warszawie, potem w ślad za tym i na prowincji ${ }^{29}$.

${ }^{26}$ W. Uziembło, Wspomnienia 1900-1939, Warszawa 1965, s. 196, 205, 239; A. Le inwand, Pogotowie Bojowe i Milicja Ludowa w Polsce 1917-1919, Warszawa 1972, s. 59-97; R. Litwiński, O polska policję..., s. 257; idem, O bezpieczeństwo wewnętrzne..., s. 228; idem, Policja Państwowa $w$ województwie lubelskim $w$ latach 1919-1939, Lublin 2001, s. 23; J. To masiewicz, P. Grudka, Paramilitarne struktury i działalność spiskowo-bojowa Polskiej Partii Socjalistycznej 1918-1928, „Bezpieczeństwo. Teoria i praktyka” 2017, nr 2, s. 92-94; J. To mas i e w i c z, Paramilitarne struktury i działalność spiskowo-bojowa polskiej prawicy 1918-1933, „Bezpieczeństwo. Teoria i praktyka” 2016, nr 2, s. 67-68, 77-78.

27 J. Moraczewski, Przewrót w Polsce, Warszawa 2015, s. 124; S. Michałowski, Myśl polityczna Polskiej Partii Socjalistycznej (1918-1939), Lublin 1994, s. 130-132.

${ }^{28}$ Obficie, w bród (franc.).

${ }^{29}$ Dziennik Juliusza Zdanowskiego, t. II, 15 X 1918-23 VI 1919, oprac. J. Faryś, T. Sikorski, H. Walczak, A. Wątor, Szczecin 2013, s. 82. 
W tym przekazie wyraźnie odnajdujemy polaryzację stanowisk prawicy i lewicy na kwestię organizacji służby bezpieczeństwa w Polsce odrodzonej.

O ile Zdanowski opowiadał się więc za czołową rolą żandarmerii, o tyle Moraczewski właśnie w żandarmerii dostrzegał zagrożenie, bowiem jak zanotował:

mieszała się do polityki, a biorąc udział w zamachach białych, służyła wyłącznie reakcji. Na prowincji była bez obsłonek narzędziem w rękach reakcjonistów, dyskredytowała wojsko w oczach ludności, która nie rozróżniając wojska od żandarmerii z powodu tożsamości munduru, wszystkie ekscesa żandarmów zwalała na karb wojska ${ }^{30}$.

Z kolei Wardęski, dostrzegając spadek popularności ML spowodowany między innymi brakiem odpowiednich kandydatów i stosownej dyscypliny, podkreślał jednocześnie sumienność, z jaką służbę traktowało wielu milicjantów. Takich ludzi było jednak zbyt mało, aby mogli oni przezwyciężyć panujący w tej formacji ogólny bezład $^{31}$.

Skomplikowana sytuacja społeczno-polityczna na przełomie 1918 i 1919 roku spowodowała, że władze zdecydowały się na rozwiązanie problemu stworzenia organizacji bezpieczeństwa publicznego w sposób długofalowy. Najpierw postanowiono ująć ML w ścisłe ramy organizacyjne i podporządkować ją rządowi. Tak więc jeszcze w grudniu 1918 roku formalnie powołano ją ,dla ochrony i zapewnienia spokoju i bezpieczeństwa ludności miast i wsi oraz walki ze wszelkimi przejawami bezładu społecznego, dla przeprowadzania zarządzeń władz państwowych"32. Zapowiedziano zorganizowanie jej na sposób wojskowy i podporządkowanie ministrowi spraw wewnętrznych. Natomiast w celu realizowania powierzonych jej obowiązków miała współpracować z samorządowymi milicjami miejskimi i milicjami powiatowymi. $\mathrm{W}$ ten sposób dokonano ostatecznie jej upaństwowienia ${ }^{33}$.

Działalność ML była jednak w dalszym ciągu problematyczna i wywoływała zróżnicowane emocje. W rozważaniach nad stanem bezpieczeństwa wewnętrznego odrodzonego państwa Stanisław Wojciechowski wspominał:

Wewnątrz [Rzeczypospolitej - R.L.], w Kaliskiem, Wieluńskiem, Biłgorajskiem uzbrojone bandy dywersantów napadały na organizujące się Wojsko Polskie, w Kieleckiem szerzył się bandytyzm, a Milicja Ludowa, powołana przez rząd dla utrzymania porządku i bezpieczeństwa, sama nieraz dawała powód do ekscesów samowolnymi wystąpieniami w Opatowskiem, Kieleckiem, Radomskiem ${ }^{34}$.

Negatywnych opinii pod adresem milicji w swym dzienniku nie szczędził tym bardziej Zdanowski, który dostrzegał pogarszający się stan bezpieczeństwa, coraz

${ }^{30}$ J. Moraczewski, op. cit., s. 124.

${ }^{31}$ H. Wardę s ki, op. cit., s. 235-236.

32 Przepisy o organizacji Milicji Ludowej z 5 grudnia 1918 r., „Dziennik Praw Państwa Polskiego” (dalej: „DzPPP”) 1918, nr 19, poz. 53.

${ }_{33}$ Ibidem; Dekret w przedmiocie uzupetnienia przepisów o organizacji Milicji Ludowej, „DzPPP” 1919, nr 14, poz. 153; W. Czapiński, Bezpieczeństwo, spokój i porządek publiczny w naszem prawie administracyjnem, „Gazeta Administracji i Policji Państwowej” 1929, nr 9, s. 317; S. Woj ci e c how ski, Moje wspomnienia, cz. II, Warszawa 2017, s. 85; R. Litwiński, O bezpieczeństwo wewnętrzne..., s. 230 .

${ }^{34}$ S. Wojciechowski, op. cit., s. 7. 
większą radykalizację społeczeństwa oraz lewicowy charakter milicyjnej organizacji, niegwarantujący jego zdaniem wypełnienia nałożonych nań zadańn ${ }^{35}$.

Następnym krokiem, jaki wobec ML zostanie podjęty w ciągu kilku miesięcy, będzie decyzja o jej rozwiązaniu. Uzmysławiano sobie bowiem sprawę z zagrożeń, jakie mogły wynikać z oparcia systemu bezpieczeństwa na tak radykalnej formacji. Warto w tym momencie przytoczyć opinię Wardęskiego na temat postawy ludowych milicjantów. Pisał on:

Chociaż był to państwowy organ bezpieczeństwa, a więc bezpartyjny, to jednak milicja bynajmniej niedwuznacznie akcentowała swoją partyjność. Oddziały Milicji Ludowej w czasie przemarszu w zwartych kolumnach niosły ostentacyjnie czerwony sztandar partyjny. Do programu piosenek żołnierskich wciągnięto tam skwapliwie i popularne pieśni rewolucyjne „Czerwony sztandar”, „Na barykady”, „Warszawiankę”, „O cześć wam, panowie magnaci” itp. Społeczeństwo nie mogło się połapać, co to za organizacja"36.

Nic więc dziwnego, że kontynuowano prace nad samorządowymi formacjami, a ich wynikiem było utworzenie Policji Komunalnej (PK), która zastąpiła Milicję Miejską. Ta druga, współpracująca przecież z władzami okupacyjnymi, nie mogła stać się podstawą służby bezpieczeństwa publicznego w odrodzonym państwie, choć dostrzegano pozytywne zmiany w zachowaniu jej funkcjonariuszy, gdy zniknęły okupacyjne ograniczenia. Policję Komunalną utworzono w styczniu 1919 roku, jako formację o charakterze samorządowym, której powierzono zapewnienie bezpieczeństwa osobistego i porządku publicznego. Była ona organem władz państwowych i samorządowych sprawującym nadzór nad przestrzeganiem przepisów prawa w zakresie czynności policji lokalnej. Jej funkcjonariusze zostali zaliczeni w poczet urzędników państwowych i byli mianowani przez ministra spraw wewnętrznych. Wszystkie dotychczas istniejące na terenie państwa organizacje bezpieczeństwa publicznego, z wyjątkiem ML, miały zostać przekształcone w policje komunalne ${ }^{37}$.

Milicja Ludowa funkcjonowała więc nadal. Dodatkowo organem odpowiedzialnym za utrzymanie bezpieczeństwa publicznego była Żandarmeria Krajowa. W tych okolicznościach ogromne problemy stwarzał przede wszystkim brak dokładnie określonych wzajemnych relacji. Słusznie przypuszczano, że może to prowadzić do powstawania sytuacji konfliktowych ${ }^{38}$.

${ }^{35}$ Dziennik Juliusza Zdanowskiego, t. II, s. 40, 49-50, 57, 59-60, 77, 90, 154, 167.

${ }^{36}$ H. Wardęski, op. cit., s. 257; R. Litwiński, O polska policję..., s. 257-258; idem, Policja Państwowa w województwie lubelskim..., s. 19-23.

${ }^{37}$ Dekret o organizacji policji komunalnej z 9 stycznia 1919 r., „DzPPP” 1919, nr 5, poz. 98; H. Czerwiński, Feljeton milicyjny, „Milicjant” 1919, nr 1, s. 6; W. Czapiński, Bezpieczeństwo, spokój i porządek publiczny w naszem..., s. 318; S. Wojciechowski, op. cit., s. 85; R. Litwiński, O bezpieczeństwo wewnętrzne..., s. 230.

${ }^{38}$ Zwracał uwagę na ten fakt m.in. Moraczewski, który podkreślając istnienie różnorodnych formacji o charakterze policyjnym, pisał: „Miasto i wieś zbroiły się w broń odebraną okupantom. Wobec wielkiego napięcia, rosnącego z dnia na dzień między partiami, tworzącymi te formacje, spodziewano się lada chwilę wybuchu walk ulicznych. Strzelanina na ulicach miasta należała do rzeczy powszednich. Zwłaszcza nocami zdawać się mogło, że bratobójcza walka już się zaczęła, tak gęsto strzelano w Warszawie, Krakowie, Lublinie, Łodzi i innych miastach". V.J. Mora c ze w s ki, op. cit., s. 79-80. 
Ale przyczyna takiego stanu rzeczy była bardziej złożona i należy się zgodzić z opinią ministra spraw wewnętrznych Wojciechowskiego, który na forum sejmowym mówił:

Ja doskonale zdaję sobie sprawę z braków, jakie ma Milicja Ludowa, i również minister spraw wojskowych jest świadomy tych braków, jakie posiada Żandarmeria Polowa. Ta sprawa jest przedmiotem naszych bezustannych zabiegów, ażeby te organy postawić na wysokości zadania i na właściwym polu działania. Naszym nieszczęściem jest nie to, że jest Milicja Ludowa, i nie to, że jest Żandarmeria Polowa, bo to stopniowo się reorganizuje i poprawia, ale to że mamy w głowie różną Polskę i nie ma jednomyślnej opinii, jaką ma być Polska. Stąd owe różnice, podszepty i rozbieżne prądy. Stąd niepokój: a może powróci ten stan rzeczy, jaki był za czasów zaborców, a z drugiej strony niepokój: może zechcą z nas zrobić republikę sowiecką. Otóż ten niepokój i stan zdenerwowania i strachu, w którem nasze społeczeństwo w ciągu 5 lat wojny pozostawało, to jest ta właśnie niezmiernie trudna sytuacja, która nie pozwala postawić organizacji służby bezpieczeństwa publicznego w szybkim tempie na wysokości zadania ${ }^{39}$.

Zaczęto więc udoskonalać istniejący aparat policyjny, ale również w dalszym ciągu poszukiwano dlań stosownego modelu organizacyjnego. Ostatecznie zdecydowano się na likwidację dotychczasowych cywilnych organów, ograniczenie uprawnień żandarmerii do osób wojskowych i powołanie nowej instytucji, której zamierzano powierzyć wyłączność na zapewnienie bezpieczeństwa publicznego na terenie kraju. Stanisław Wojciechowski, podczas swego sejmowego wystąpienia, konkludował: „W Polsce powinien być i będzie jeden tylko organ [bezpieczeństwa publicznego]” Ale osiągnięcie wysokiego stopnia profesjonalizacji każdej służby wymagało czasu. Tym bardziej dotyczyło to państwa odradzającego się po długoletniej niewoli. Państwa, które nie posiadało odpowiednich kadr w wystarczającej liczbie i które próbowało scalić trzy różne systemy administracyjne. Dostrzegał to również sam Wojciechowski. Dlatego apelował, aby społeczeństwo tak szanowało polską policję, jak on nauczył się szanować policję angielską w trakcie pobytu w Wielkiej Brytanii ${ }^{41}$.

16 maja 1919 roku na sali sejmowej zaprezentowano projekt ustawy o utworzeniu Straży Bezpieczeństwa, przygotowany przez komendanta głównego PK i ML Kazimierza Młodzianowskiego oraz szefa Sekcji II MSW Stefana Urbanowicza. Straż miała być państwową organizacją bezpieczeństwa publicznego, bo model samorządowy nie zdał egzaminu. Doświadczenie pokazywało, że władze lokalne rzadko dostrzegały problem bezpieczeństwa publicznego w zakresie szerszym niż własna gmina. Tymczasem odrodzone państwo potrzebowało formacji odpowiednio wyszkolonej, realizującej zadania o zasięgu ogólnokrajowym i scentralizowanej w zakresie procesu decyzyjnego. Stąd wynikało podporządkowanie jej ministrowi spraw

${ }^{39}$ Sprawozdanie stenograficzne z 16. posiedzenia Sejmu Ustawodawczego z dn. 20 III 1919 r., 1. 869-871.

${ }^{40}$ Ibidem, ł. 870. Tę różnorodność policyjnych formacji Wardęski wspominał następująco: „Dalsze istnienie kilku organizacji bezpieczeństwa stało się niemożliwe; trzeba było powziąć jakąkolwiek decyzję na zasadzie faktów dotychczasowej działalności tych organów. Jeden z tych organów musiał wchłonąć inne. Nareszcie po wielu bolesnych eksperymentach władze przekonały się, że unifikacja organizacji bezpieczeństwa staje się koniecznością państwową". Zob. H. Wardęs ki, op. cit., s. 260.

${ }^{41}$ Sprawozdanie stenograficzne z 16. posiedzenia Sejmu Ustawodawczego z dn. 20 III 1919 r., 1. 875; R. Litwińs ki, O bezpieczeństwo wewnętrzne..., s. 232. 
wewnętrznych. Nowa organizacja miała swe zadania wykonywać zarówno w imieniu władz państwowych, jak i samorządowych ${ }^{42}$. Stanisław Wojciechowski relacjonował: „W projekcie ustawy policję nazwałem rozmyślnie »Straż Bezpieczeństwa«, ponieważ ludzie wartościowi, których chciałem pozyskać dla tej służby, wzdragali się na sam wyraz »policja«, poprzednio zaś chętnie służyli w strażach obywatelskich, jakie powstawały w okresie okupacji" ${ }^{43}$. Ostatecznie jednak sejmowa Komisja Administracyjna zaproponowała zmianę nazwy na „Policja Państwowa”, a przymiotnik dodano w celu podkreślenia jej państwowego i scentralizowanego charakteru ${ }^{44}$.

Ostatecznie także w odrodzonej Rzeczypospolitej opowiedziano się za koncepcją cywilnej, ogólnopaństwowej i scentralizowanej formacji policyjnej. 24 lipca 1919 roku Sejm uchwalił ustawę o Policji Państwowej, która jako organ wykonawczy władz państwowych i samorządowych miała za zadanie ochronę bezpieczeństwa, spokoju i porządku publicznego. Została ona zorganizowana i wyszkolona na wzór wojskowy ${ }^{45}$. W zakresie zwalczania przestępczości kryminalnej i antypaństwowej nowa policja została podporządkowana przedstawicielom rządu, tj. wojewodom w województwach i starostom - na terenie powiatów. To władze administracyjne były więc odpowiedzialne za kreowanie polityki bezpieczeństwa i stanowiły ośrodek decyzyjny. Poza tym w trakcie prowadzenia dochodzeń funkcjonariusze PP podlegali urzędom wymiaru sprawiedliwości ${ }^{46}$.

Okazało się jednak, że pomimo dążeń do scentralizowania aparatu policyjnego w odrodzonym kraju nie do końca nowa organizacja bezpieczeństwa publicznego była formacją ogólnopaństwową. U podłoża tego stanu rzeczy leżał statut organiczny województwa śląskiego, nadający temu obszarowi szczególną autonomię. W związku z tym Policja Państwowa nie pojawiła się w tamtejszym województwie. Służbę bezpieczeństwa publicznego objęła tam odrębna Policja Województwa Śląskiego, chociaż tworzona na podobieństwo PP. Była ona organem wykonawczym tamtejszych władz wojewódzkich ${ }^{47}$. Choć funkcjonowanie tych dwóch formacji w kolejnych latach było przyczyną licznych problemów organizacyjnych i formalnych, to stanowiło przecież przejaw uszanowania odrębności województwa śląskiego. Co ciekawe,

42 Sprawozdanie stenograficzne z 39. posiedzenia Sejmu Ustawodawczego z dn. 16 V 1919 r., 1. XXXIX/4-XXXIX/6; S. Wojciechowski, op. cit., s. 86.

${ }^{43}$ S. Wojciechowski, op. cit., s. 87.

${ }^{44}$ Ibidem, s. 88; R. Litwińs ki, O bezpieczeństwo wewnętrzne..., s. 232.

${ }^{45}$ Sprawozdanie stenograficzne z 76. posiedzenia Sejmu Ustawodawczego z dn. 24 VII 1919 r., 1. LXXVI/4-LXXVI/26; Ustawa z dnia 24 lipca 1919 roku o policji państwowej, „DzPPP” 1919, nr 61, poz. 363; R. Litwiński, O bezpieczeństwo wewnętrzne..., s. 233.

46 Ustawa z dnia 24 lipca 1919 roku o policji państwowej, „DzPPP” 1919, nr 61, poz. 363.

${ }^{47}$ Rozporzadzenie z dnia 17. czerwca 1922 r.w przedmiocie organizacji Policji Województwa Śląskiego, „Dziennik Ustaw Śląskich” (dalej: „DzUŚl.”), 1922, nr 1, poz. 4; Przepisy przejściowe do rozporzadzenia o Policji Wojewódzkiej, „DzUŚl.” 1922, nr 1, poz. 5; Rozporzadzenie Prezydenta Rzeczypospolitej z dnia 28 października 1933 r. o stużbie w Policji Województwa Ślaskiego, „Dziennik Ustaw Rzeczypospolitej Polskiej” (dalej: „DzURP”) 1933, nr 86, poz. 662; J. Mikitin, Geneza instytucji policyjnych na Ślasku w latach 1918-1922 [w:] Administracja bezpieczeństwa na terenie województwa ślaskiego w latach 1922-1939, red. D. Gre gorczy k, A. O si erda, Bielsko-Biała 2010, s. 69-76; idem, Policja Województwa Śląskiego 1922-1939 [w:] Administracja bezpieczeństwa ..., s. 77-97; R. Li twiński, O bezpieczeństwo wewnętrzne..., s. 234-235. 
niemal przez całe dwudziestolecie przewijała się kwestia upaństwowienia śląskiej policji. Jednak mimo że pomysł ten popierały również władze wojskowe, do przyjęcia takiego rozwiązania nie doszło. W konsekwencji system policyjny II Rzeczypospolitej do końca jej istnienia składał się z dwóch bliźniaczych organizacji - PP i PWŚl, a ich podobieństwo było tak duże, że niekiedy sami decydenci nie czynili pomiędzy nimi rozróżnienia ${ }^{48}$.

Podsumowując, należy zaznaczyć, że początkowe pomysły dotyczące stworzenia organizacji bezpieczeństwa publicznego, które pojawiły się latem 1914 roku, były spowodowane bardziej lokalnymi potrzebami i nakazami chwili niż chęcią stworzenia instytucji o szerszym zakresie działalności. Niemniej jednak odegrały one ogromną rolę, bowiem spowodowały nie tylko pojawienie się czynnika obywatelskiego, ale również wymusiły jego rozwój w poszczególnych miastach Królestwa w późniejszym czasie, przyczyniając się do szerszego zaangażowania samorządów w sprawy bezpieczeństwa publicznego. Kolejnym etapem były już koncepcje wybiegające w przyszłość, do odrodzonej Rzeczypospolitej, które pojawiły się na początku 1917 roku wraz z Tymczasową Radą Stanu. Opowiadały się one za zarzuceniem wzorca samorządowego i wprowadzeniem modelu państwowej organizacji bezpieczeństwa publicznego.

Już u progu niepodległości nadal zastanawiano się jednak, czy za bezpieczeństwo wewnętrzne powinna odpowiadać instytucja państwowa, czy liczne formacje samorządowe. W konsekwencji proces wyłaniania formacji policyjnej był długotrwały i obfitował w liczne rozwiązania prawne, które ostatecznie doprowadziły do utworzenia scentralizowanej formacji - Policji Państwowej oraz uzupełniającej ją Policji Województwa Śląskiego. W zakresie wykonywania służby bezpieczeństwa obie zostały uzależnione od władz administracji państwowej ${ }^{49}$.

\section{BIBLIOGRAFIA}

\section{Źródła archiwalne}

Archiwum Państwowe w Lublinie, Lubelski Obywatelski Komitet Gubernialny, Wstęp do inwentarza.

Biblioteka Uniwersytecka Katolickiego Uniwersytetu Lubelskiego, Archiwum Jana Steckiego, rkps 571 .

${ }^{48}$ R. Litwiński, Korpus policji w II Rzeczypospolitej. Stużba i życie prywatne, Lublin 2007, s. 281-283.

${ }^{49}$ R. Litwiński, O bezpieczeństwo wewnętrzne..., s. 241-242. 


\section{Źródła drukowane}

Dekret o organizacji policji komunalnej z 9 stycznia 1919 r., „Dziennik Praw Państwa Polskiego" 1919, nr 5, poz. 98.

Dekret w przedmiocie uzupełnienia przepisów o organizacji Milicji Ludowej, „Dziennik Praw Państwa Polskiego" 1919, nr 14, poz. 153.

Kalendarzyk Polityczno-Historyczny miasta stołecznego Warszawy na 1917 rok, Warszawa b.d.w.

Księga pamiątkowa Straży Obywatelskiej st. m. Warszawy i Przedmieść 5.VIII.1915 31.1.1916, oprac. J. P., Warszawa-Lwów 1916.

Okupacja Warszawy. Zbiór dokumentów i głosów prasy dotyczących sprawy polskiej w związku z zajęciem Warszawy przez wojska niemieckie. Sierpień 1915 r., Fryburg 1915.

Przepisy o organizacji Milicji Ludowej z 5 grudnia 1918 r., „Dziennik Praw Państwa Polskiego" 1918, nr 19, poz. 53.

Przepisy przejściowe do rozporządzenia o Policji Wojewódzkiej, „Dziennik Ustaw Śląskich” 1922, nr 1, poz. 5.

Regulamin stużbowy dla Milicji Miejskiej st. m. Warszawy, Warszawa 1916.

Rozporządzenie Prezydenta Rzeczypospolitej z dnia 28 października 1933 r. o służbie w Policji Województwa Śląskiego, „Dziennik Ustaw Rzeczypospolitej Polskiej” 1933, nr 86, poz. 662.

Rozporządzenie z dnia 17. czerwca 1922 r. w przedmiocie organizacji Policji Województwa Śląskiego, „Dziennik Ustaw Śląskich” 1922, nr 1, poz. 4.

Sprawozdanie Komitetu Obywatelskiego 1915 r. Część 2-ga (okres od 5 sierpnia do 31 grudnia 1915 r.), Warszawa 1917.

Sprawozdanie Komitetu Obywatelskiego miasta Warszawy. Sierpień - grudzień 1914, Warszawa 1915.

Sprawozdanie stenograficzne z 16. posiedzenia Sejmu Ustawodawczego z dnia 20 III 1919 r. Sprawozdanie stenograficzne z 39. posiedzenia Sejmu Ustawodawczego z dnia 16 V 1919 r. Sprawozdanie stenograficzne z 76. posiedzenia Sejmu Ustawodawczego z dn. 24 VII 1919 r. Ustawa z dnia 24 lipca 1919 roku o policji państwowej, „Dziennik Praw Państwa Polskiego” 1919, nr 61, poz. 363.

Uwagi ogólne o organizacji policji w Król. Polskiem, „Milicjant” 1919, nr 2.

\section{Dzienniki i wspomnienia}

Dziennik Juliusza Zdanowskiego, t. I, 22 VI 1915 - 29 IV 1917, oprac. J. Faryś, T. Sik or ski, H. Walc zak, A. W ąt or, Szczecin 2013.

Dziennik Juliusza Zdanowskiego, t. II, 15 X 1918 - 23 VI 1919, oprac. J. Faryś, T. Sikor ski, H. Walczak, A. W ątor, Szczecin 2013.

Moraczews ki J., Przewrót w Polsce, Warszawa 2015.

Uziembło W., Wspomnienia 1900-1939, Warszawa 1965.

Wardęs ki H., Moje wspomnienia policyjne, Warszawa 1926.

Woj ciechow ski S., Moje wspomnienia, cz. II, Warszawa 2017. 


\section{Opracowania i artykuły monograficzne}

A bramski A., Ko nieczny J., Justycjariusze, hutmani, policjanci. Z dziejów stużb ochrony porzadku w Polsce, Katowice 1987.

Czapiń ski W., Bezpieczeństwo, spokój i porzadek publiczny w naszem prawie administracyjnem, „Gazeta Administracji i Policji Państwowej” 1929, nr 9.

Czerwińs ki H., Feljeton milicyjny, „Milicjant” 1919, nr 1.

Dziesięciolecie Stużby Bezpieczeństwa w Polsce Odrodzonej, red. E. Grabow i e c ki, Warszawa 1925.

Gryz G., Milicja Miejska miasta stołecznego Warszawy [w:] Od straży obywatelskich do Policji. Stużby porzadkowe na ziemiach polskich $w X X$ wieku, red. R. Łaszewski, B. Sprenge1, Włocławek 2007.

Kochanowski J., O ksztatt polskiej policji - styczeń 1917 - listopad 1918, „Przegląd Historyczny" 1986, t. LXXVII, z. 3.

Kramarz H., Samorzad Lwowa $w$ czasie pierwszej wojny światowej $i$ jego rola $w \dot{z} y c i u$ miasta, Kraków 1994.

Krońs ki A., Straż Obywatelska m. st. Warszawy 1915 roku, Warszawa 1934.

Le in w and A., Pogotowie Bojowe i Milicja Ludowa w Polsce 1917-1919, Warszawa 1972.

Litwińs ki R., Korpus policji w II Rzeczypospolitej. Stużba i życie prywatne, Lublin 2007.

Litwiński R., O bezpieczeństwo wewnętrzne odrodzonej Rzeczypospolitej, „Przegląd Historyczno-Wojskowy" 2018, nr 1-2.

Litwiński R., O polska policję. Koncepcje organizacji bezpieczeństwa publicznego na ziemiach polskich w czasie Wielkiej Wojny [w:] Lata Wielkiej Wojny. Dojrzewanie do niepodległości 1914-1918, red. D. Grinberg, J. S nopko, G. Zakiewicz, Białystok 2007.

Litw iń s ki R., Policja Państwowa w województwie lubelskim w latach 1919-1939, Lublin 2001.

Michałowski S., Myśl polityczna Polskiej Partii Socjalistycznej (1918-1939), Lublin 1994.

Mikitin J., Geneza instytucji policyjnych na Ślasku w latach 1918-1922 [w:] Administracja bezpieczeństwa na terenie województwa ślaskiego w latach 1922-1939, red. D. G r egorc zy k, A. Osi erda, Bielsko-Biała 2010.

Mikitin J., Policja Województwa Ślaskiego 1922-1939 [w:] Administracja bezpieczeństwa na terenie województwa ślaskiego w latach 1922-1939, red. D. Gregorczyk, A. Osierda, Bielsko-Biała 2010.

Misiuk A., Tworzenie się polskich organów policyjnych $w$ okresie I wojny światowej (1914-1918), „Problemy Kryminalistyki” 1987, nr 176.

P ająk J.Z., O rząd i armię. Centralny Komitet Narodowy (1915-1917), Kielce 2003.

S tar ościak W., Kazimierz Srokowski-pierwszy przewodniczacy Rady Miejskiej w latach 1917-1924, „Raptularz Kulturalny” 2005, nr 1.

Strzelecki W., Bezpieczeństwo na ziemiach Polski. Od kmiecia grodowego do granatowej armii, Warszawa 1934.

To mas i ew ic z J., Grudka P., Paramilitarne struktury i działalność spiskowo-bojowa Polskiej Partii Socjalistycznej 1918-1928, „Bezpieczeństwo. Teoria i praktyka” 2017, nr 2.

To m a s i e w i c z J., Paramilitarne struktury i działalność spiskowo-bojowa polskiej prawicy 1918-1933, „Bezpieczeństwo. Teoria i praktyka” 2016.

Zahorski A., Centralne instytucje policyjne w Polsce $w$ dobie rozbiorów, Warszawa 1959. 